Araştırma Makalesi

\title{
Üniversite Öğrencilerinin Özçekim Davranışları: Yeni Medyanın Etkin Kullanıcıları Olarak İletişim Öğrencileri Üzerinde Bir Araştırma
}

\author{
Ali Şimşek (Prof. Dr.)
}

Anadolu Üniversitesi İletişim Bilimleri Fakültesi asimsek@anadolu.edu.tr

Taner Kızılhan (Arş. Gör. Dr.)

(iD) Adnan Menderes Üniversitesi İletişim Fakültesi tanerkizilhan@gmail.com

Kemal Elciyar (Arş. Gör. Dr.)

Anadolu Üniversitesi İletişim Bilimleri Fakültesi kemalelciyar@anadolu.edu.tr

Başvuru Tarihi: 17.02.2021

Yayına Kabul Tarihi: 20.05.2021

Yayınlanma Tarihi: 30.07.2021

https://doi.org/10.17680/erciyesiletisim.881846

Öz

Fotoğraf temelli sosyal ağların yaygınlığı son dönemde hızlı bir ivme kazanmış, mobil telefonların gelişen kamera özellikleri de bu olguyu artırmıștır. Bu araştırma, iletişim fakültesi öğrencilerinin özçekim davranışlarını bazı kişisel ve demografik değişkenler açısından karşılaştırmalı olarak incelemek amacıyla yapılmıştır. Genel tarama modelinde yürütülen araștırmanın evreni, mobil teknolojiler konusunda, başka alanlardaki akranlarına oranla, görece daha yetkin olduğu varsayılan iletişim fakülteleri öğrencilerinden oluşmuştur. Araștırma örnekleminde Türkiye'deki iki devlet ve iki vakıf üniversitesinin iletişim fakültelerinde öğrenim gören toplam 613 lisans öğrencisi yer almıştır. Veriler, Balakrishnan ve Griffiths (2018) tarafından geliștirilen ve çeşitli ülkelerdeki araştırmalarda yaygın biçimde kullanılan Likert türü Özçekim Saplantısı Davranış Ölçeği ile toplanmıştır. Verilerin çözümlenmesinde hem betimsel hem yordamsal istatistiksel tekniklerden yararlanılmıştır. Sonuçlar göstermektedir ki, öğrencilerin cinsiyeti ve üniversite türünün (devlet-vakıf) genel özçekim saplantı düzeyi üzerinde anlamlı bir etkisi yoktur. Buna karşılık, öğrencilerin öğrenim gördükleri üniversiteler, bölümler, dönemler ile kullandıkları mobil telefonların markası ve günlük mobil telefon kullanım süreleri açısından anlamlı farklılıklar bulunmuştur. Ayrıca, üniversite türü dışında, neredeyse tüm bağımsız değişkenler açısından özçekim saplantısının alt boyutları üzerinde anlamlı farklılıklar belirlenmiştir.

Anahtar Kelimeler: İletişim, Özçekim, Özçekim Saplantısı, Özçekim Davranışları, Mobil Telefon, Üniversite Öğrencileri. 


\title{
Selfie Behaviors of University Students: A Study on Communication Students as Active Users of New Media
}

\author{
Ali Şimşek (Prof. Dr.)
}

iD Anadolu University Faculty of Communication asimsek@anadolu.edu.tr

Taner Kızılhan (Res. Asst. Ph.D.)

D Adnan Menderes University Faculty of Communication tanerkizilhan@gmail.com

Kemal Elciyar (Res. Asst. Ph.D.)

iD Anadolu University Faculty of Communication kemalelciyar@anadolu.edu.tr

Date Received: 17.02 .2021

Date Accepted: 20.05.2021

Date Published: 30.07.2021

https://doi.org/10.17680/erciyesiletisim.881846

\begin{abstract}
The prevalence of photo-based social networks has recently gained a significant momentum and the evolving camera features of mobile phones have also increased this phenomenon. The purpose of the present study was to compare selfie behaviors of communication students in Turkey from the point of some personal and demographic variables. The study was conducted as a survey study. The population of the study was identified as communication students who are assumed to be more proficient than their peers in other areas when it comes to the use of mobile media. The sample of the study consisted of 613 undergraduate students from two state-owned and two foundationowned universities. The Likert-type "Selfitis Behavior Scale" developed by Balakrishnan and Griffiths (2018) was administered to collect data. The results of the study yielded no significant effect for gender of the participants and university types on overall level of selfie behaviors. However, significant differences were found regarding the effects of universities, departments, years of study, brands of mobile phone used, and daily durations of mobile phone usage. In addition, a number of significant differences were detected in terms of the sub-dimensions of selfie behaviors in relation to almost all independent variables, except university type.
\end{abstract}

Keywords: Communication, Selfie, Selfitis, Selfie Behaviors, Mobile Phone, University Students. 


\section{Giriş}

Günümüzde, özellikle bireysel iletişim düzeyinde, özçekimin ${ }^{1}$ (selfie) temel görsel iletişim biçimi olduğu bir dünyada yaşamaktayız. Yaş, eğitim düzeyi, etnik grup gibi farklı sinıflandırmalarda yer alan insanlar, kendilerini sosyal medya üzerinden özçekim yoluyla kolayca ifade etmektedirler. Öyle ki, 2016 yılında çeşitli sosyal medya platformlarından toplam 26 milyarın üzerinde özçekim paylaşılmıştır. Bununla birlikte, yapılan araștırmalarda (Zetlin, 2019) iki binli yıllarda doğan ortalama bir bireyin yaşamı boyunca yaklaşık 25,000 özçekim paylaşacağı öngörülmüştür.

Özçekim konusuna yönelik yaklaşımlar, özçekimin farklı yönlerini ele almış; bir yandan bu yeni olgunun yarattığı firsatlar vurgulanmıș, bir yandan da getirdiği tehlikeler tartışılmıştır. Konuyla ilgili yaklaşımlar alanlar itibariyle de farklılaşmaktadır. Örneğin, fotoğraf sanatı açısından ele alındığında özçekimler, sanatsal çalışmanın, sanatçının tekelinde olmadığı ve sıradan bireylerin de özgün yapıtlar üretebildiği bir otoportre biçimi olarak görülmüştür. Bu yönüyle özçekim olumlu olarak değerlendirilmiştir (Saltz, 2014). İletişim açısından ise özçekim, zaman zaman bireyin sosyal medyada kullandığı bir sözsüz iletişim biçimi olarak tartışılmıştır. Dolayısıyla, iletişim açısından da bir olumlama söz konusudur. Özçekimlere olumsuz yaklaşan alanlar ve çalışmalar da vardır. Özellikle psikoloji alanındaki çalışmalar çok sayıda özçekim yapmanın, bunları sosyal medyada paylaşmanın ve öteki bireylerin paylaştıkları özçekimleri düzenli olarak takip etmenin ergenler ve genç yetişkinler üzerinde olumsuz etkiler yarattığını ortaya koymuştur. Alanyazında bu durum tutkulu, aşırı ya da saplantılı özçekim davranışı anlamına gelen "selfitis" kavramıyla ifade edilmektedir (Şimșek, 2020).

Özçekim saplantısına ilişkin hasta öykülerinin ortaya çıkışını izleyen yıllarda konu uluslararası alanyazında çeşitli disiplinlerden araştırmacılar tarafından incelenmeye başlanmıştır. Araştırmacılar çeşitli ölçekler kullanarak bu olguya ilişkin genel durumu ortaya koymaya ve işlevsel öneriler sunmaya çalışmışlardır. Balakrishnan ve Griffith'in 2018 yılında geliştirmiş oldukları "Özçekim Saplantısı Davranış Ölçeği” (Selfitis Behavior Scale) bu ölçeklerden biri olup, bugüne kadar birçok araştırmacı tarafından çeşitli ülkelerde kullanılmıștır Türkiye'de ise, araștırmacıların saptayabildiği kadarıyla, konuya ilişkin henüz yeterli çalışmanın yapılmadığı görülmüştür.

$\mathrm{Bu}$ arka plan dikkate alınarak bu araştırmanın temel amacı, iletişim fakültelerindeki öğrencilerin saplantılı özçekim davranışlarının genel durumunu bireylerin özçekim davranışlarını etkileme olasılığı bulunan kişisel ve demografik değişkenler açısından karşılaştırmalı olarak incelemek biçiminde belirlenmiştir. Bu temel amaca dönük olarak aşağıdaki araştırma sorularına yanıt aranmıştır:

1. Üniversitelerdeki iletişim öğrencilerinin saplantılı özçekim davranışları genel olarak hangi düzeydedir?

2. Saplantılı özçekim davranışlarının alt boyutları arasında düzey bakımından anlamlı farklılıklar var mıdır?

3. Saplantılı özçekim davranışları devlet ve vakıf üniversitesi olma durumuna göre farklılık göstermekte midir?

4. Demografik/kişisel değişkenler açısından üniversite öğrencilerinin saplantılı özçekim davranışlarında farklılık gözlenmekte midir? 


\section{Literatür Taraması}

\section{1. Özçekimin Tanımı ve Tarihçesi}

Geçmişi otoportre çeken ilk fotoğraf meraklılarına kadar uzanmakla birlikte, özçekim (selfie) kavramı, Oxford Sözlüğü tarafından, 2013'te yılın sözcügü seçildikten sonra çok popüler hale gelmiş ve araştırmalara konu olmaya başlamıştır. Sözlük, özçekimi bir "akıllı telefon ya da kamera ile bireyin kendi fotoğrafını çekmesi ve bunu sosyal medyada paylaşması" olarak tanımlamıștır (Oxford Dictionaries, 2013).

Sayısal (digital) teknolojilerin ve çift taraflı merceklerle fotoğraf çekebilme özelliği olan akıllı telefonların gelişmesiyle gittikçe yaygınlaşan özçekim olgusu, yine akıllı telefonlar sayesinde sosyal medyanın mobil teknolojilerle bütünleşmesiyle birlikte, başka bir boyut kazanmış ve bu teknolojilere erişebilen bireylerin gündelik yaşamlarının ayrılmaz bir parçası, neredeyse olağan bir davranışı haline gelmiştir. Artık bireyler gerçekleştirdikleri etkinliklere ilişkin olarak kendi başlarına ya da başkalarıyla, çektikleri özçekimleri herhangi bir sosyal medya uygulaması üzerinden paylaşabilir hale gelmişlerdir.

Bu durum öyle bir noktaya ulaşmıştır ki, Peraica (2017) gibi bazı yazarlar özçekimi bir kültür olarak ele almaya başlamışlardır. Wallop'un (2014), ABD'deki 86. Akademi Ödülleri Töreni'nde gerçekleşen bir olaya ilişkin anekdotu da aslında Peraica'nın düşüncelerini destekler niteliktedir. Bu olay daha sonra geleneksel medyaya da sıklıkla haber olmuştur: Dolby Theatre'ın izleyicilerle dolu olduğu, büyük televizyon kameralarının çekim yaptığı bir alanın ortasında Bradley Cooper'ın kullandığı akıllı telefonla 12 ünlü özçekim yapmış ve ardından bunu paylaşmıştır. Bu kare, izleyen günlerde milyonlarca başka kullanıcı tarafından kendi listelerindeki bireylerle paylaşılmıştır.

Tarihsel olarak bakıldığında, otoportrenin üretimi ve paylaşımının aslında yeni bir durum olmadığı görülmektedir. Picasso, Albrecht Dürer ve Van Gogh kimi ressamlar aslında sayısal tekniğin olanaklarının kullanılmaya başlanmasından çok önceleri kendi otoportrelerini yapmışlardır. Otoportrelerin üretiminde tekniğin olanaklarının kullanılmaya başlanması ise kameranın bulunmasına kadar götürülebilir. Kamera kullanılarak çekilen ilk otoportrenin "dagerreyotopi" (daguerreotype) adı verilen bir süreçle 1839 yılında Robert Cornelius tarafından çekildiği bilinmektedir (McConnell, 2015). Buna karşın özçekim olgusu, kısa ama hızlı gelişen bir tarihe sahiptir. Özçekimin sayısal teknolojiler ve sosyal medya uygulamalarıyla bağlantısı ancak on yılı aşkın bir süredir görülmektedir.

Özçekim hakkındaki söylemler ve tartışmalar daha çok popüler kültürle iç içe görünmektedir. Çoğunlukla gazeteler, internet ve televizyon haberlerinde yer almaktadır. Reklamlarda da sıcça kullanılmaktadır. Losse (2013), özçekimlerin sosyal medyanın gelişiminden önce mahrem bir alan olduğunu iddia etmektedir. Bugün sosyal medyanın gelişimi, akıllı telefonların yaygınlaşması ve sanal kültürün ortaya çıkması, özçekimler için deyim yerindeyse verimli bir ortam sunmaktadır.

Günümüzde anladığımız şekliyle özçekim (selfie) sözcüğünü ilk olarak 2002 yılında Avustralya'daki bir blog yazarı kullanmıştır. Özçekim kavramının internetteki sosyal paylaşım ağlarındaki ilk kullanılışı ise 2004 yılında "Flickr" sitesinde olmuştur (Uzundumlu, 2015). Günümüzde özçekimlerin büyük çoğunluğu akıllı telefonlar kol uzunluğunda tutularak yapılmaktadır. Teknolojik gelişmeler ile birlikte akıllı telefonların ön yüzlerine de kamera eklenmiş ve bu aygitlar daha kullanıcı dostu olmuştur. Bu durum, özçekim yapan kişiye, ekranda çekecek olduğu nesneyi tümüyle görme, çerçevelemede 
kontrol sağlama, istediği gibi odaklama ve pozlama yapma olanakları getirmiștir (Şimşek, 2020).

Özçekim günümüzde neredeyse herkes tarafından bilinen bir kavram ve çok yaygın olarak gerçekleşen bir olgudur. Katz ve Crocker'ın Amerika Birleşik Devletleri'nde, İngiltere'de ve Çin'de, 18-24 yaş bireyler üzerinde, bireylerin özçekim alışkanlıklarına ilişkin olarak yaptıkları çalışma, katılımcıların \%96'sından fazlasının özçekim yaptığını ortaya koymuştur (Katz ve Crocker, 2015). Türkiye'de ise bu olguya ilişkin böyle bir istatistiksel bir veriye ulaşılamamış olmakla birlikte, özçekim yapmak her mobil medya kullanıcısı için sıradan denecek kadar yaygın bir olaydır.

Bireyler neden özçekim yapmakta, paylaşmakta, başkalarının paylaştığı özçekimleri takip etmekte ve kendisine gelenleri yeniden paylaşmaktadırlar? Yapılan araştırmalar, özçekimin bu kadar yaygınlaşmasının arkasında pek çok farklı güdünün olduğunu ortaya koymuştur. Yapılan bazı çalışmalar, özçekim yapan ve paylaşan bireylerin, özsever (narsistik) eğilimlere sahip olduklarını göstermiştir (Etgar ve Amichai-Hamburger, 2017). Ancak bu etken özçekim paylaşımının arkasındaki tek güdü değildir. Bunun dışında aynı deneyimi yaşayamayan insanlara deneyime ilişkin gerçek zamanlı güncellemeler sunma (Paris ve Pietschnig, 2015), izlenim yönetimi ve özsünüm (Ellison, Heino ve Gibbs, 2006), bir etkinlikte bulunduğunu kanıtlama, yaşıtlarından geribildirim alma (Katz ve Crocker, 2015), yaşanılanı ya da deneyimi anı olarak saklama gibi nedenlerle de özçekim paylaşımı yapılmaktadır.

Özçekimlerin bireylerin yaşamlarında bazı olumlu etkileri olduğu bir gerçektir. Günümüzde birçok insan masrafsız ve hızlı fotoğraf çekimlerini çeşitli elektronik aygıtlarla yapmaktadır. Sosyal medya ve bağlantılı araç ya da uygulamalar yardımıyla arzulanan benlik sunumunun gerçekleştirilmesi olanaklıdır. Bu sayede istendik benliğin sunumu ve kimliğin yönetilmesi sağlanabilmektedir. Özçekimler, bireylerin kimliklerini ifade etmesine, istenen ya da algllanan benliklerini yansitmalarına izin vermektedir. Bununla birlikte, özçekimler pek çok olumsuz etkiyi de beraberinde getirmiştir. Bunların başında alanyazında özçekim saplantısı (selfitis) olarak adlandırılan psikolojik rahatsızlık gelmektedir.

\section{2. Özçekim Saplantısının Boyutları}

Özçekim saplantısı, "bireylerin benlik saygılarındaki eksikliği gidermek ve öteki insanlarla samimi olamamanın oluşturduğu boşluğu doldurmak amacıyla bireyin kendi fotoğrafını çekme ve bunu sosyal medyada paylaşmaya olan takıntılı-saplantılı arzuyu" ifade eden psikolojik bir rahatsızlık olarak görülmektedir (Donitta, 2017, s. 985). Bu rahatsızlığı Türkçede kısaca "özçekim saplantısı" olarak adlandırmak olanaklıdır (Şimşek, 2020). Bu rahatsızlık, bireyin güzel görünmeye ve bunu başkalarına göstermeye yönelik beğenilme arzusundan kaynaklanmaktadır. Balakrishnan ve Griffiths'in (2018) belirttiği üzere, özçekim saplantısı, rahatsızlığın şiddetine göre üç farklı düzeyde olabilmektedir. Bunları şu şekilde belirtmek olanaklıdır (2018):

1. Sınıra yakın (Borderline) özçekim saplantısı: Günde 3 adete kadar özçekim yapmayı fakat bunları sosyal medyada paylaşmamayı içerir.

2. Akut özçekim saplantısı: Günde en az 3 özçekim yapmayı ve çektiklerini sosyal medyada paylaşmayı içerir.

3. Kronik özçekim saplantısı: Günde en az altı özçekim yapmayı ve bunların her birini sosyal medyada paylaşmayı içerir. 
Özçekim saplantısı; güvenlik riski yaratması, bağımlılığa sebep olması, insan ilişkilerine zarar verebilmesi, fiziksel görünüșe çok fazla vurgu yapması gibi nedenlerle bir hastalık olarak adlandırılabilmektedir (Donitta, 2017, s. 985). Bu hastalık, modern dünyanın özgün bir hastalığı olmakla birlikte, farklı psikolojik rahatsızlıklarla da yakından ilişkili görünmektedir. Söz konusu rahatsızlıklar; obsesif-kompulsif bozukluk, beden dismorfik bozukluğu ve özseverlik şeklinde sıralanabilir. Yine özçekim saplantısının psikiyatride karanlık üçlü (dark triad) adı verilen ve Makyavelizm, özseverlik ve psikopatiyi içeren hastalıklı kişilik özellikleriyle de yakından ilişkili olduğu üzerinde durulmaktadır. Bu üç kişilik özelliği aldatma, kendini pazarlama, soğukluk, anlaşmazlık, sömürü ve saldırganlık gibi ortak özellikleri paylaşmaktadır (Bergkvist, 2016, s. 6).

Fox ve Rooney'e (2015) göre karanlık üçlü, öz-nesneleștirmeyle yakından ilişkilidir ve bu ilişkiyi özçekim saplantısı oldukça iyi yansıtmaktadır. Aynı yazarlar, kişilik özellikleri ile özçekim saplantısı arasındaki ilişkiyi, bireylerin kendilerinin kurguladıkları ve paylaştıkları özçekim sayısı üzerinden anlamaya çalışmışlardır. Yaptıkları araştırma, öngörüleriyle tutarlı sonuçlar vermiștir. Buna göre; öz-nesneleştirme ve özseverlik, sosyal medyada geçirilen zamanı; özseverlik ve psikopati paylaşılan özçekim sayısını; özseverlik ve öz-nesneleștirme ise kişinin kendisiyle ilgili paylaştığı fotoğrafları kurgulamasını öngörmektedir. Ayrıca öz-nesneleştirme, özseverlik, Makyavelizm, psikopati ve yaş değişkenleri ile sosyal paylaşım sitelerinde harcanan zaman ve paylaşılan özçekim sayısı arasında da ilişki bulunmuştur (Fox ve Rooney, 2015).

Alanyazındaki tartışmalardan anlaşıldığı kadarıyla, özçekim saplantısı, üzerinde önemle durulması gereken ve hem bireysel hem de toplumsal olarak olumsuz sonuçlar doğurabilecek bir rahatsızlık olarak karşımıza çıkmaktadır. Bu da sorunun dünyada ve Türkiye'de neden gittikçe artan sayıda araştırmaya konu olduğunu açıklamaktadır.

\subsection{Dünya'da ve Türkiye'de Özçekim Saplantısı Araştırmaları}

Türkiye'de özçekim konusuyla ilgili yapılan araştırmalara bakıldığında, bunların daha çok betimsel düzeyde kaldığı ve bireylerin özçekim alışkanlıklarını farklı yönleriyle inceleyen çalışmalar olduğu görülmektedir. Özçekim saplantısına ilişkin vurgular ise daha çok ulusal gazetelerdeki haberler düzeyinde kalmıştır.

Dünyadaki alanyazına bakıldığında ise, birçok ülkede konuya ilişkin değişik araștırmalar yapıldığı görülmektedir. $\mathrm{Bu}$ araştırmaların önemli bir bölümü bireylerin özçekim yapmalarının ve paylaşmalarının arkasındaki güdüler üzerinde durmuştur. Pek çok ülkede gerçekleştirilen araştırmalar bireyleri özçekime iten farklı güdü kaynakları bulmuştur. Georgakopoulou (2016), özçekimlerin paylaşılmasının ve kullanıcıların özçekimlerle etkileşim kurmalarının, öykü oluşturma ve oluşturulan öyküleri paylaşma rolleriyle yakından ilişkili olduğunu saptamıştır. Sung, Lee, Kim ve Choi (2016), bireyleri özçekim paylaşmaya yönelten dört güdünün varlığını ortaya koymuşlardır: ilgi arayışı, iletişim, arşivleme ve eğlence. Mehdizadeh'e (2010) göre, kullanıcılar fotoğraf paylaşarak, profil bilgileriyle ve duvar içerikleriyle özsunum (self-presentation) gereksinimlerini karşılamaktadırlar. Bunlarla birlikte, bireyler, bir topluluk içerisinde var olma, beğenilme, popüler olma gibi çok sayıda farklı gerekçelerle özçekim yapmakta ve paylaşabilmektedirler.

Yapılan çalışmalar genel olarak özçekim saplantısının gerek karanlık üçlü adı verilen kişilik özellikleriyle gerekse obsesif-kompulsif bozukluk, beden dismorfik bozukluğu ve özseverlik gibi kișilik bozukluklarıyla yakından ilișkili olduğunu ortaya koymuștur. En 
büyük vurgu ise, özseverlik ve özçekim arasındaki ilişki üzerine olmuştur. Özseverler (narsistler), hassas ve kırılgan öz imajlarını korumak için başkalarının ilgisine ve hayranlı̆̆ına gereksinim duymaktadırlar. Özçekimlerde bu yönde kullanılan unsurlar olmaktadır. Nitekim araştırmalara göre, özsever kişilerin sosyal ağlardaki kendi tanıtımını yapma (self-promoting) düzeyleri daha yüksek çıkmaktadır (Buffardi ve Campbell, 2008).

Sorokowski, Sorokowska, Frackowiak, Huk ve Pisanski (2015), özseverlik eğilimine sahip bireylerin başka bireylere göre daha çok özçekim paylaştıkları varsayımıyla Polonya'da başlattıkları araştırmada, kadınların erkeklerden daha çok özçekim paylaşmalarına karşın paylaştıkları özçekimlerin özseverlikten bağımsız olduğunu ortaya koymuşlardır. Erkeklerin ise özçekim paylaşırken daha özseverlik odaklı güdülendiklerini ortaya koymuşlardır. Bu yönüyle Sorokowski ve diğerlerinin çalışması paylaşılan özçekim sayısıyla özseverlik değişkeni arasında belirgin bir ilişkinin olmadığını ortaya koymuştur. Ancak yapılan birçok başka çalışmada bunun tersi yönde sonuçlar bulunmuştur. Nitekim Weiser'in (2015) ABD'de yaptığı çalışmanın yanı sıra; Halpern, Valenzuela ve Katz'ın (2016) Şili'de gerçekleştirdikleri çalışmada özçekim paylaşımı ve özseverlik arasında pozitif bir ilişki bulmuşlardır. Bu durum, özçekim ve özseverlik arasındaki ilişkinin kültürel farklılıklardan etkileniyor olabileceğini göstermektedir.

Özçekim saplantısına ilişkin araştırmaların vurgu yaptığı bir başka önemli nokta ise özçekimler ile bireylerin özsaygıları arasındaki ilişkidir. Shin, Kim, Im ve Chong'un (2017) Güney Kore'de gerçekleştirdikleri araştırmanın sonuçları, özçekim yapmanın ve paylaşmanın, yapan kişilerde toplumsal duyarlılığa ve özsaygı düşüklüğüne neden olduğunu göstermiştir. Wang, Yang ve Haigh'in (2017) ABD’de gerçekleștirdiği araștırma da benzer bir sonuç ortaya koymuştur. Söz konusu araştırma, yapılan bireysel özçekimlere düzenli olarak bakmanın bireylerin özsaygısını düşürdüğünü; grup özçekimlerine bakmanın ise yükselttiğini göstermiştir. Bu konuda farklı ülkelerde yapılan çalışmalar benzer sonuçlar vermektedir.

Döring, Reif ve Poeschl'in (2016) Almanya'da yaptıkları araştırmada 500 adet özçekim içerik çözümlemesi yoluyla incelenmiştir. Ardından bu özçekimler, magazin dergilerindeki cinsiyet kalıpyargısını oluşturucu görsellerle karşılaştırılmıştır. Sonuç olarak, özçekimlerin yalnızca cinsiyet kalıpyargısı oluşturmadığı, bunu magazin dergilerinden çok daha etkili bir biçimde yaptığı ortaya çıkmıștır.

Bazarova ve Choi'nin (2014) araştırmasında da özçekim paylaşımına yönelik bazı güdüler ortaya çıkmıştır: kimlik açıklama, ilişkisel gelişim, toplumsal onaylama, toplumsal denetim, kendini ifade etme, rahatlama, eğlence, bilgi paylaşımı ve depolama. Ayrıca alanyazındaki öteki araştırmalarda; sevgi, dikkat çekme, açıllama, zaman geçirme, bilgi paylaşımı ve sosyal etki (Malik, Dhir ve Nieminen, 2016); kendini koruma, iletişim ve eğlence (Holiday, Lewis, Nielsen, Anderson ve Elinzano, 2016); sosyal etkileşim, arşivleme, kendini ifade etme ve göz atma (Lee, Lee, Moon ve Sung, 2015); ilgi arayışı, iletişim, arşivleme ve eğlence (Sung ve diğerleri, 2016)particularly selfies (pictures one takes of oneself gibi boyutların altı çizilmektedir.

Buraya kadar özetlenen bilgiler ışığında bu araştırma, Balakrishnan ve Griffiths'in (2018) geliştirdiği ve çeşitli araştırmalarda kullanılan ölçeğin (Özçekim Saplantısı Davranış Ölçeği) boyutları üzerinden özçekim saplantısını araştırmaktadır. Çalışma, özellikle yeni teknolojilere açık olduğu ve bunları etkin biçimde kullandığı varsayılan iletişim öğrencilerinin, özçekim saplantısıyla ilgili durumlarını belirlemeyi ve çeşitli değişkenler açısından aralarında anlamlı farklılıklar olup olmadığını incelemeyi amaçlamaktadır. 


\section{Yöntem}

Araştırma genel tarama modelinde yürütülmüştür. Yansız örnekleme tekniği ile örneklem alınmış ve araştırmaya ilişkin olarak yapılan açıklamalardan sonra katılımcılar gönüllülük ilkesi doğrultusunda çalışmaya katılmışlardır.

Araștırmaya 2 devlet üniversitesi (Anadolu ve Adnan Menderes) ve 2 vakıf üniversitesi (Başkent ve İzmir Ekonomi) dâhil edilerek araştırma verileri bu üniversitelerin iletişim fakültelerinden toplanmıştır. $\mathrm{Bu}$ ikili seçimin altında yatan neden, sosyoekonomik durumun, öğrencilerin özçekim paylaşımlarına bir etkisinin olup olmadığını belirleme çabasıdır. Buna göre örneklem; 348 (\%57) öğrenci devlet üniversitelerinden, 265 (\%43) öğrenci ise vakıf üniversitelerinden olmak üzere toplam 613 lisans öğrencisinden oluşmuştur.

Araștırmaya yedi farklı bölümden öğrenciler katılmıștır. Bu bölümleri "İletişim Tasarımı ve Yönetimi”, "Basın ve Yayın”, "Gazetecilik", "Halkla İlişkiler ve Reklamcılık", "Sinema ve Televizyon", "Medya ve İletişim" ile "Sinema ve Dijital Medya” olarak sıralamak olanaklıdır. Örneklemdeki öğrencilerin yaklaşık yarısı (\%47) Reklamcılık ve Halkla İlişkiler Bölümü öğrencisidir. Bunu İletişim Tasarımı ve Yönetimi Bölümü (\%19) ile Sinema ve Televizyon (\%17) Bölümü izlemektedir. Geri kalan öğrenciler küçük yüzdelerle öteki beş bölüme dağılmıştır.

Araștırmaya 335 (\%55) kadın, 278 (\%45) erkek öğrenci katılmıștır. Katılımcıların 208'i (\%34) Anadolu Üniversitesi'nde, 140’ı (\%23) Adnan Menderes Üniversitesi'nde, 135'i (\%22) Başkent Üniversitesi'nde, 130'u (21) İzmir Ekonomi Üniversitesi'nde öğrencidir. Bu öğrencilerin 187'si (\%31) dördüncü dönemlerinde, 236'sı (\%39) altıncı dönemlerinde, 123'ü (\%20) sekizinci dönemlerinde bulunmaktadırlar. Geri kalan (\%10) kesimdeki 67 öğrenci ise çeşitli nedenlerle dönem kaydırmıș öğrencilerdir.

Araştırmaya katılan 613 öğrencinin tümünün mobil telefonu vardır. Bunlar markalarına göre incelendiğinde yarıdan fazlası (\%52) tek başına Apple ürünüdür. İkinci sırada \%26'lık bir pay ile Samsung gelmekte, bunu \%15'lik pay ile Huawei izlemektedir. Öteki telefon markalarının toplam içindeki payı \%8 kadardır. Öğrencilerin sahip oldukları telefonları günde kaç saat kullandıklarına bakıldığında ise \%73'ü mobil telefonunu günde 1-5 saat arasında kullandığını bildirmiştir. Günde 5 saatten çok kullananların oranı bile \%23 düzeyindedir. Bu değerler göstermektedir ki, iletişim öğrencileri mobil telefonlarını günlük yaşamda yoğun biçimde kullanmaktadırlar.

Çizelge 1. Katılımcıların Alt Gruplara Göre Dağılımı

\begin{tabular}{|l|l|c|c|}
\hline Değişkenler & \multicolumn{1}{|c|}{$\mathbf{n}$} & \% \\
\hline \multirow{2}{*}{ Cinsiyet } & Kadın & 335 & 54.6 \\
\cline { 2 - 4 } & Erkek & 278 & 45.4 \\
\hline \multirow{3}{*}{ Üniversite Türü } & Devlet & 348 & 56.8 \\
\cline { 2 - 4 } & Özel & 265 & 43.2 \\
\hline \multirow{3}{*}{ Üniversite } & Anadolu & 208 & 33.9 \\
\cline { 2 - 4 } & Adnan Menderes & 140 & 22.8 \\
\cline { 2 - 4 } & Başkent & 135 & 22.0 \\
\cline { 2 - 4 } & İzmir Ekonomi & 130 & 21.2 \\
\hline
\end{tabular}




\begin{tabular}{|c|c|c|c|}
\hline Değişkenler & & $\mathbf{n}$ & $\%$ \\
\hline \multirow{7}{*}{ Bölüm } & İletişim Tasarımı ve Yönetimi & 117 & 19.1 \\
\hline & Basın ve Yayın & 48 & 7.8 \\
\hline & Gazetecilik & 4 & 0.7 \\
\hline & Reklamcılık ve Halkla İlişkiler & 285 & 46.5 \\
\hline & Sinema ve Televizyon & 105 & 17.1 \\
\hline & Medya ve İletişim & 29 & 4.7 \\
\hline & Sinema ve Dijital Medya & 25 & 4.1 \\
\hline \multirow{8}{*}{ Dönemler } & İkinci Yarıyıl & 9 & 1.5 \\
\hline & Üçüncü Yarıyıl & 15 & 2.4 \\
\hline & Dördüncü Yarıyıl & 187 & 30.5 \\
\hline & Beşinci Yarıyıl & 13 & 2.1 \\
\hline & Altıncı Yarıyı & 236 & 38.5 \\
\hline & Yedinci Yarıyıl & 8 & 1.3 \\
\hline & Sekizinci Yarıyıl & 123 & 20.1 \\
\hline & Sekiz Üzeri & 22 & 3.6 \\
\hline \multirow{4}{*}{ Cep Telefonu Markaları } & Apple & 317 & 51.7 \\
\hline & Samsung & 159 & 25.9 \\
\hline & Huawei & 91 & 14.8 \\
\hline & Diğerleri & 46 & 7.5 \\
\hline \multirow{4}{*}{ Cep Telefonu Kullanımları } & 1 saatten az & 26 & 4.2 \\
\hline & 1-3 saat & 242 & 39.5 \\
\hline & 4-5 Saat & 203 & 33.1 \\
\hline & 5 saatten fazla & 142 & 23.2 \\
\hline
\end{tabular}

Çalışmada veri toplama aracı olarak Janarthanan Balakrishnan ve Mark D. Griffiths (2018) tarafından bireylerin özçekim saplantı düzeylerini belirlemek amacıyla geliştirilen ve çeşitli ülkelerdeki benzer araştırmalarda yaygın olarak kullanılan "Özçekim Saplantısı Davranış Ölçeği” (Selfitis Behavior Scale), Türkçe'ye çevrilmiş; geçerlilik ve güvenilirlik analizleri yapıldıktan sonra araştırmacıların gözetiminde katılımcılara sınıf ortamında ve yüz yüze olarak uygulanmıștır. Saplantı kavramı, "selfitis" kavramının rahatsızlık belirten yönünü vurgulamak üzere Türkçe bir öneri olarak kullanılmıştır.

Ölçeğin pilot uygulaması Anadolu Üniversitesi İletişim Bilimleri Fakültesi'nden seçilen 78 kişilik bir öğrenci grubuyla yapılmıştır. Pilot uygulamadan sonra ölçeğin tümü için hesaplanan Cronbach Alfa katsayısı 0,94 olarak bulunmuştur. Pilot uygulamada alt kategoriler itibariyle bakıldığında en düşük güvenirlik katsayısı "toplumsal yarışma" için 0,70 olarak hesaplanırken en yüksek güvenirlik katsayısı "duygudurum değişikliği" için 0,85 olarak bulunmuștur. Pilot uygulamadan sonra ölçekte ciddi bir değișiklik yapılmamıș, yalnızca küçük bazı yazım hataları düzeltilmiştir.

Araştırmada kullanılan veri toplama aracı iki bölümden oluşmuştur. İlk bölümde, katılımcıların özçekim yapma ve paylaşma konusundaki davranışlarının derecesini belirlemek için 20 maddeden oluşan Likert tipi bir ölçek kullanılmıştır. Bu ölçek altı alt boyutu kapsamaktadır. Bunlar: özgüven (self confidence), dikkat arayıșı (attention seeking), duygudurum değişikliği (mood modification), çevre genişletme (environmental enhancement), öznel uygunluk (subjective conformity) ve toplumsal yarışma (social competition) şeklindedir. Ölçekte çevre genişletme ve toplumsal yarışma boyutlarında dörder madde yer alırken öteki boyutların her birinde üçer madde yer almıştır. Veri toplama aracının ikinci bölümü ise katılımcıların demografik verilerini (cinsiyet, 
üniversite, bölüm, dönem, mobil telefon markası ve günlük mobil telefon kullanım süresi vb.) toplamaya yönelik 5 maddeden oluşmuştur.

Son uygulamada ölçek için hesaplanan Cronbach alfa güvenirlik katsayısı ise 0,95 olarak bulunmuş ve alanyazında belirtilen ölçüt değerler dikkate alındığında bunun oldukça yüksek bir güvenirlik katsayısı olduğu kabul edilmiştir. Ölçeğin alt kategorileri açısından en düşük güvenirlik katsayısı "çevre genişletme" için 0,73 olarak hesaplanırken en yüksek güvenirlik katsayısı "duygudurum değișikliği” için 0,86 olarak bulunmuştur. Bu sonuçlar göstermektedir ki, güvenirlik katsayısı açısından pilot uygulama ile araştırma için verilerin toplandığı son uygulamadan elde edilen değerler birbirine çok yakındır.

\section{Etik Kurul İzni}

Anadolu Üniversitesi Sosyal ve Beșeri Bilimler Bilimsel Araştırma ve Etik Kurulu'nun 26.04.2018 tarih ve 43348 numaralı toplantısında alınan karar çerçevesinde çalışma etik açıdan bir sakınca içermemektedir.

\section{Bulgular}

Ölçek uygulamasının ardından öğrencilerden toplanan veriler araştırma amaçları doğrultusunda ve uygun istatistiksel teknikler kullanılarak çözümlenmiştir. Bu çözümlemeler sonucunda ulaşılan betimsel ve yordamsal bulgular çizelgelerde sunulmuş ve izleyen paragraflarda yorumlanmıștır. Tersi belirtilmediği sürece, istatistiksel karşılaştırmalarda anlamlılık değeri olarak 0.05 temel alınmıştır. Ancak 0.01 düzeyinde anlamlı fark bulunduğunda bu ayrıca belirtilmiștir.

\section{1. Özçekimin Alt Boyutları Arasındaki Korelasyonlar}

Öğrencilerin saplantılı özçekim davranışlarının düzeyini belirlemek amacıyla kullanılan ölçeğin alt kategorileri arasındaki ilişkiler çapraz olarak incelenmiş ve elde edilen korelasyon katsayıları Çizelge 2'de yansıtılmıştır.

Çizelge 2. Özçekim Saplantısının Boyutları Arasındaki Korelasyonlar

\begin{tabular}{|l|c|c|c|c|c|c|}
\hline & 1 & 2 & 3 & 4 & 5 & 6 \\
\hline 1.Çevre genişletme & 1 & & & & & \\
\hline 2.Toplumsal yarışma & $.965^{\star \star}$ & 1 & & & & \\
\hline 3.İgi arayışı & $.659^{\star \star}$ & $.687^{\star \star}$ & 1 & & & \\
\hline 4.Duygu-durum değişikliği & $.658^{\star \star}$ & $.660^{\star \star}$ & $.735^{\star \star}$ & 1 & & \\
\hline 5.Özgüven & $.693^{\star \star}$ & $.687^{\star \star}$ & $.742^{\star \star}$ & $.818^{\star \star}$ & 1 & \\
\hline 6.Öznel uygunluk & $.532^{\star \star}$ & $.589^{\star \star}$ & $.725^{\star \star}$ & $.679^{\star \star}$ & $.641^{\star \star}$ & 1 \\
\hline
\end{tabular}

Özçekim davranışlarını belirlemeye yönelik alt boyutlar çevre genişletme, toplumsal yarışma, dikkat arayışı, duygudurum değişikliği, kendine güven ve öznel uygunluk olarak belirtilmişti. Bunlar arasındaki ilişkinin yönünü ve düzeyini saptamak için gerçekleştirilen korelasyon analizinde, her alt boyutun birbiriyle pozitif yönlü ve görece yüksek düzeyde bir ilişkiye sahip olduğu görülmüştür. Ölçeğin alt boyutları arasında en yüksek korelasyon katsayısı çevre genişletme ve toplumsal yarışma arasında ( $\mathrm{r}=.965)$ gözlenirken, en düşük korelasyon katsayısı ise öznel uygunluk ve çevre genişletme arasında $(\mathrm{r}=.532)$ bulunmuștur.

\subsection{Değişkenlerin Etkileri Yönünden Karşılaştırmalar}

Araştırmada özçekim saplantısına yönelik yedi boyut (ölçek geneli ve alt boyutlar) ve yedi bağımsız değişken (demografik ve kişisel boyutlar) bulunduğu için karşılaştırmalardaki 
farklılıkların anlamlı olup olmadığını belirlemede uygun olduğu varsayılan istatistiksel çözümleme tekniklerinden çoklu varyans analizi (MANOVA) kullanılmıştır. MANOVA'nın kullanılması için bağımlı değişkenleri bir arada incelemeye yönelik kavramsal bir neden bulunmalıdır. MANOVA, ortalamalar ve standart sapmaları dikkate alarak grupları karşılaştırır ve bağımlı değişkenlerin birleşimi üzerinde, ortalama farklarının istatistiksel açıdan anlamlı olup olmadığını belirtir (Tabachnick ve Fidell, 2013).

Veri toplama aracı olarak kullanılan ölçeğin geneli ve alt boyutlarında öğrencilerin ortalama puanları cinsiyet, üniversite türü (devlet-vakıf), öğrenim gördükleri üniversite ve kullandıkları mobil telefon markalarına göre incelenmiştir.

\subsubsection{Cinsiyet}

Kadınlar ve erkekler arasında modelde yer alan faktörler açısından anlamlı bir farklılık olup olmadığının görülmesi için analizler yapılmış ve istatistiksel açıdan anlamlı farklar bulunmuştur $\left[F(6,606)=5,29, \mathrm{p}<.001\right.$, Pillai's Trace $\left.=.050, \mathrm{n}_{\mathrm{p}}{ }^{2}=.050\right]$. Bağımlı değişkenler Bonferroni uyarlanmış alfa düzeyi .008 kullanılarak tek tek ele alındığında çevre genişletme $\left[F(1,611)=7,02, \mathrm{p}<.01, \mathrm{n}_{\mathrm{p}}{ }^{2}=.011\right]$ ve öz güven $\left[F(1,611)=7,87, \mathrm{p}<.01, \mathrm{n}_{\mathrm{p}}{ }^{2}=.005\right]$ boyutlarında anlamlı farklılıklar vardır. Çevre genişletme boyutunda ortalamalar kadınlar için $(M=2.64)$ ve erkekler için $(M=2.44)$ şeklindedir. Özgüven boyutunda ise kadınlar $(M=2.20)$, erkekler $(M=1.97)$ ortalamalara sahiptir.

\subsection{2. Üniversite Türü}

Araştırma modelinde yer alan tüm boyutlarda vakıf üniversitelerinin ortalama puanı devlet üniversitelerinin ortalama puanından aritmetik anlamda daha yüksektir. $\mathrm{Bu}$ farklılıkların anlamlı olup olmadığı incelendiğinde gözlenen farklılıkların istatistiksel yönden anlamlı olmadığı görülmüştür $[F(6,606)=2,27, \mathrm{p}=.411$, Pillai's Trace=.010, $\left.\mathrm{n}_{\mathrm{p}}^{2}=.010\right]$. Dolayısıyla gruplararası etkiler incelenmemiştir.

\subsection{3. Üniversiteler}

Araştırmanın yürütüldüğü dört üniversite içinde en yüksek özçekim saplantı puanına (altı alt boyutun genel ortalaması) sahip öğrenciler Adnan Menderes Üniversitesi'nin öğrencileri $(M=2,36)$ olmuş, bunu Başkent Üniversitesi öğrencileri $(M=2,11)$ ve İzmir Ekonomi Üniversitesi öğrencileri $(M=2,09)$ izlemiştir. En düşük özçekim saplantı puanına sahip olanlar ise Anadolu Üniversitesi'nin öğrencileri $(M=1,81)$ olmuştur. Üniversiteler yönünden özçekim saplantısı boyutlarında anlamlı bir farklılık olup olmadığına yönelik analizler yapılmıștır. Sonuçlar bu farklılıkların anlamlı olduğunu göstermektedir $\left[F(18,1708)=3,19, \mathrm{p}<.001\right.$, Pillai's Trace $\left.=.092, \mathrm{n}_{\mathrm{p}}{ }^{2}=.031\right]$. Bağıml değişkenler tek tek ele alındığında, tüm boyutlarda anlamlı farklılıklar görülmüştür: çevre genişletme $[F(3,609)$ $\left.=15,85, \mathrm{p}<.001, \mathrm{n}_{\mathrm{p}}{ }^{2}=.072\right]$, toplumsal yarışma $\left[F(3,609)=14,73, \mathrm{p}<.001, \mathrm{n}_{\mathrm{p}}{ }^{2}=.068\right]$, ilgi arayışı $\left[F(3,609)=8,25, \mathrm{p}<.001, \mathrm{n}_{\mathrm{p}}{ }^{2}=.039\right]$, duygu-durum değişikliği $[F(3,609)=11,81$, $\left.\mathrm{p}<.001, \mathrm{n}_{\mathrm{p}}{ }^{2}=.055\right]$, öz güven $\left[F(3,609)=8,09, \mathrm{p}<.001, \mathrm{n}_{\mathrm{p}}{ }^{2}=.038\right]$, öznel uygunluk $[F(3,609)$ $\left.=6,78, \mathrm{p}<.001, \mathrm{n}_{\mathrm{p}}{ }^{2}=.032\right]$. Üniversitelere göre ortalamalar Çizelge 3'de görülmektedir.

Çizelge 3. Üniversitelere Göre Ortalama Puanlar

\begin{tabular}{|l|c|c|c|c|c|c|}
\hline & $\begin{array}{c}\text { Çevre } \\
\text { genişletme }\end{array}$ & $\begin{array}{c}\text { Toplumsal } \\
\text { yarışma }\end{array}$ & ilgi Arayışı & $\begin{array}{c}\text { Duygu durum } \\
\text { değişikliği }\end{array}$ & Öz güven & $\begin{array}{c}\text { Öznel } \\
\text { uygunluk }\end{array}$ \\
\hline Anadolu & 2.23 & 2.11 & 1.63 & 1.61 & 1.87 & 1.43 \\
\hline Adnan Menderes & 2.90 & 2.71 & 2.13 & 2.24 & 2.39 & 1.82 \\
\hline Başkent & 2.60 & 2.46 & 1.89 & 1.90 & 2.15 & 1.66 \\
\hline İzmir Ekonomi & 2.64 & 2.50 & 1.86 & 1.82 & 2.09 & 1.59 \\
\hline
\end{tabular}




\subsubsection{Bölümler}

Üniversitelerin iletişim fakültelerinde yer alan bölümler açısından özçekim saplantısının boyutları konusundaki durum incelenmiştir. Sonuçlar, farklılıkların anlamlı olduğunu göstermektedir $\left[F(36,3636)=2,02, \mathrm{p}<.001\right.$, Pillai's Trace $\left.=.118, \mathrm{n}_{\mathrm{p}}{ }^{2}=.020\right]$. Bağıml değişkenler tek tek ele alındığında dört boyutta anlamlı farklılıklar görülmüştür: çevre genişletme $\left[F(6,606)=5,92, \mathrm{p}<.001, \mathrm{n}_{\mathrm{p}}{ }^{2}=.055\right]$, toplumsal yarışma $[F(6,606)=5,84$, $\left.\mathrm{p}<.001, \mathrm{n}_{\mathrm{p}}^{2}=.055\right]$, ilgi arayıșı $\left[F(6,606)=2,96, \mathrm{p}=.007, \mathrm{n}_{\mathrm{p}}{ }^{2}=.028\right]$, duygu-durum $[F(6,606)$ $\left.=3,00, \mathrm{p}=.007, \mathrm{n}_{\mathrm{p}}{ }^{2}=.029\right]$. Öteki boyutlardaki farklar anlamlı değildir. Bölümlere göre ortalamalar ise Çizelge 4'te sunulmuştur.

Çizelge 4. Bölümlere Göre Ortalama Puanlar

\begin{tabular}{|l|c|c|c|c|c|c|}
\hline & $\begin{array}{c}\text { Çevre } \\
\text { genişletme }\end{array}$ & $\begin{array}{c}\text { Toplumsal } \\
\text { yarışma }\end{array}$ & İlgi Arayışı & $\begin{array}{c}\text { Duygu durum } \\
\text { değişikliği }\end{array}$ & Öz güven & $\begin{array}{c}\text { Öznel } \\
\text { uygunluk }\end{array}$ \\
\hline $\begin{array}{l}\text { İletişim Tasarımı } \\
\text { ve Yönetimi }\end{array}$ & 2.28 & 2.18 & 1.79 & 1.75 & 1.95 & 1.60 \\
\hline Basın ve Yayın & 2.02 & 1.87 & 1.42 & 1.39 & 1.78 & 1.30 \\
\hline Gazetecilik & 2.56 & 2.31 & 2.08 & 2.17 & 2.17 & 1.58 \\
\hline $\begin{array}{l}\text { Reklamcılık ve } \\
\text { Halk. İliş. }\end{array}$ & 2.70 & 2.54 & 1.94 & 1.96 & 2.19 & 1.66 \\
\hline Sinema ve TV & 2.62 & 2.46 & 1.79 & 1.98 & 2.13 & 1.55 \\
\hline Medya ve Iletişim & 2.75 & 2.57 & 1.74 & 1.70 & 2.05 & 1.53 \\
\hline $\begin{array}{l}\text { Sinema ve } \\
\text { Dijital Medya }\end{array}$ & 2.56 & 2.52 & 2.16 & 1.91 & 2.29 & 1.93 \\
\hline
\end{tabular}

\subsubsection{Dönem/Yıl}

Veriler Bahar döneminde toplandığı, birinci yılını doldurmamış öğrenciler araștırmaya dahil edilmediği, dönem kaydırmış öğrencilerin durumlarında bazı belirsizlikler bulunduğu ve olağan dönemler dışındaki dönemlerde olduğunu belirtenlerin sayılarının olağan dönemlerdekilerden ciddi biçimde az olduğu dikkate alınarak, öğrencileri 2., 3. ve 4. yıllara ayırarak ortalamaları üzerinden karşılaştırmalar yapmanın daha sağlıklı olacağı düşünülmüștür.

Dönemler üzerinden özçekim saplantısı boyutları incelenmiştir. Sonuçlar, farklılıkların anlamlı olduğunu göstermektedir $[F(12,1212)=2,27, \mathrm{p}=.007$, Pillai's Trace $=.044$, $\left.\mathrm{n}_{\mathrm{p}}{ }^{2}=.022\right]$. Bağımlı değişkenler tek tek ele alındığında öznel uygunluk dışında tüm boyutlarda anlamlı farklılıklar görülmüştür: çevre genişletme $[F(2,610)=11,05, \mathrm{p}<.001$, $\left.\mathrm{n}_{\mathrm{p}}{ }^{2}=.035\right]$, toplumsal yarışma $\left[F(2,610)=10,03, \mathrm{p}<.001, \mathrm{n}_{\mathrm{p}}{ }^{2}=.032\right]$, ilgi arayışı $[F(2,610)$ $\left.=6,25, \mathrm{p}<.01, \mathrm{n}_{\mathrm{p}}{ }^{2}=.020\right]$, duygu-durum $\left[F(2,610)=9,23, \mathrm{p}<.001, \mathrm{n}_{\mathrm{p}}{ }^{2}=.029\right]$, özgüven $\left[F(2,610)=7,05, \mathrm{p}<.01, \mathrm{n}_{\mathrm{p}}{ }^{2}=.023\right]$. Dönemlere göre ortalamalar Çizelge 5 'de verilmiştir.

Çizelge 5. Dönemlere Göre Ortalama Puanlar

\begin{tabular}{|l|c|c|c|c|c|c|}
\hline & $\begin{array}{c}\text { Çevre } \\
\text { genişletme }\end{array}$ & $\begin{array}{c}\text { Toplumsal } \\
\text { yarışma }\end{array}$ & İlgi Arayışı & $\begin{array}{c}\text { Duygu durum } \\
\text { değişikliği }\end{array}$ & Öz güven & $\begin{array}{c}\text { Öznel } \\
\text { uygunluk }\end{array}$ \\
\hline 2. yıl & 2.77 & 2.60 & 2.01 & 2.08 & 2.28 & 1.68 \\
\hline 3. yıl & 2.51 & 2.38 & 1.82 & 1.81 & 2.07 & 1.60 \\
\hline 4. yıl & 2.31 & 2.19 & 1.67 & 1.65 & 1.89 & 1.50 \\
\hline
\end{tabular}

\subsubsection{Mobil Telefon Markası}

Mobil telefon markalarına göre özçekim saplantısı ortalamalarına bakıldığında en yaygın kullanılan iPhone, Samsung ve Huawei gibi markaların ortalama puanları başka kategorisinde yer alan markalardan farklıdır. Birbiriyle neredeyse aynı ortalamaya sahip 
olan Samsung $(M=2,02)$ ve Huawei $(M=2,03)$ markaları bir yana bırakılırsa, en yüksek ortalamaya sahip iPhone $(M=2,13)$ ile en düşük ortalamaya sahip başka kategorisindeki markaların $(M=1,68)$ ortalaması arasındaki fark belirgindir. Genel olarak mobil telefon markalarının özçekim saplantısı üzerindeki etkisine ilişkin farkların anlamlılığı istatistiksel açıdan test edildiğinde, gözlemlenen farklar anlamsız bulunmuştur $\left[F(18,1818)=2,27, \mathrm{p}=.129\right.$, Pillai's Trace $\left.=.041, \mathrm{n}_{\mathrm{p}}{ }^{2}=.014\right]$. Özçekim saplantısı boyutları ile mobil telefon markaları arasında bir ilişki yoktur.

\subsubsection{Günlük Mobil Telefon Kullanım Süresi}

Günlük mobil telefon kullanım süresi bir değișken olarak alınarak, bu değişkenin özçekim saplantısı üzerinde bir etkisinin olup olmadığına bakılmıştır. Genel olarak akılcı ve normal bir kullanım süresi olarak görülen günlük 1-3 saat kategorisi dışında, günlük kullanım süresi arttıkça özçekim saplantı puanı yükselmektedir. Özellikle mobil telefonunu günde 5 saatten çok kullananların ortalaması $(M=2,32)$ ile günde 1 saatten az kullananların ortalaması $(M=2,04)$ arasındaki fark oldukça belirgindir.

Çizelge 6. Mobil Telefon Kullanım Sürelerine Göre Ortalama Puanlar

\begin{tabular}{|l|c|c|c|c|c|c|}
\hline & $\begin{array}{c}\text { Cevre } \\
\text { genişletme }\end{array}$ & $\begin{array}{c}\text { Toplumsal } \\
\text { yarışma }\end{array}$ & İlgi Arayışı & $\begin{array}{c}\text { Duygu durum } \\
\text { değişikliği }\end{array}$ & 0̈z güven & $\begin{array}{c}\text { Öznel } \\
\text { uygunluk }\end{array}$ \\
\hline 1 saatten az & 2.38 & 2.29 & 1.78 & 1.93 & 2.29 & 1.60 \\
\hline 1-3 saat & 2.33 & 2.19 & 1.67 & 1.70 & 1.96 & 1.46 \\
\hline 4-5 saat & 2.67 & 2.54 & 1.91 & 1.94 & 2.13 & 1.74 \\
\hline 5 saatten çok & 2.78 & 2.61 & 2.07 & 2.03 & 2.25 & 1.64 \\
\hline
\end{tabular}

Özçekim saplantı boyutları üzerinden günlük kullanım süresi ortalamalarına ilişkin farkların anlamlılığı istatistiksel açıdan test edildiğinde aradaki farklar anlamlı bulunmuştur $\left[F(18,1818)=2,27, \mathrm{p}<.001\right.$, Pillai's Trace $\left.=.087, \mathrm{n}_{\mathrm{p}}{ }^{2}=.029\right]$. Alt boyutlara göre yapılan anlamlılık testleri de özgüven hariç tüm boyutlarda anlamlı farklılıklar ortaya koymuştur: çevre genişletme $\left[F(3,609)=8,92, \mathrm{p}<.001, \mathrm{n}_{\mathrm{p}}{ }^{2}=.042\right]$, toplumsal yarışma $\left[F(3,609)=9,47, \mathrm{p}<.001, \mathrm{n}_{\mathrm{p}}^{2}=.045\right]$, ilgi arayışı $\left[F(3,609)=6,15, \mathrm{p}<.001, \mathrm{n}_{\mathrm{p}}^{2}=.029\right]$, duygudurum değişikliği $\left[F(3,609)=4,12, \mathrm{p}=.007, \mathrm{n}_{\mathrm{p}}{ }^{2}=.020\right]$, öznel uygunluk $[F(3,609)=4,53$, $\left.\mathrm{p}=.004, \mathrm{n}_{\mathrm{p}}^{2}=.022\right]$.

\section{Sonuçlar, Tartışma ve Öneriler}

Bu araştırma, Türkiye'deki iletişim fakültelerinde öğrenim gören öğrencilerin özçekim saplantısına ilişkin durumlarını uluslararası düzeyde yaygın olarak kullanılan veri toplama araçlarına dayalı olarak belirlemek ve çeşitli değişkenler açısından alt gruplar arasında anlamlı farklar bulunup bulunmadığını sınamak amacıyla gerçekleştirilmiştir. Genel tarama modelinde yürütülen araştırmada toplanan veriler üzerinde betimsel ve yordamsal istatistik tekniklerinden yararlanılarak araştırma amaçlarına yönelik çözümlemeler gerçekleștirilmiştir. Araştırmada ulaşılan sonuçlar aşağıda sunulmuş ve ilgili alanyazın bağlamında tartışılmıştır.

Araştırmaya katılan öğrencilerin toplam özçekim saplantısına ilişkin puanlarının ortalaması $(M=2,06)$ dikkate alındığında, genel saplantı düzeyinin düşük düzeyde olduğu belirtilebilir. Alt boyut ortalamalarına bakıldığında ise en yüksek değer çevre genişletme $(M=2,55)$, en düşük değer öznel uygunluk $(M=1,60)$ boyutlarında ortaya çıkmıştır. Öteki boyutların ortalamaları, verilen uç değerler arasındadır. Buradan hareketle, araştırmaya katılan öğrencilerin özçekim saplantısı düzeylerinin bazı boyutlarda henüz başlangıç aşamasında olduğu ama bazı boyutlarda biraz ilerlemiş bulunduğu dikkati çekmektedir. Balakrishnan ve Griffiths'in (2018) özçekim davranış bozukluğunun düzeylerini her 
kullanıcının günlük paylaşım sayısı üzerinden belirlediği düşünülürse, aslında bu araştırmada paylaşılan fotoğraf ya da video miktarından çok, alt boyutlara göre özçekim davranışlarını tetikleyen güdülerin düzeyleri belirlenmiştir. Ulaşılan sonuçlar da hem genel hem alt boyutlar itibariyle öğrencilerin güdü düzeyinin, beş dereceli Likert tipi ölçekler için temel alınan eşik değerin $(3,41 / 5,00)$ altında olduğunu göstermektedir. Bu da iletişim öğrencilerinin özçekim davranışları konusunda görece dikkatli ya da bilinçli davrandıklarını göstermektedir.

Ölçek uygulamasından elde edilen toplam özçekim saplantısı puanları cinsiyet açısından incelendiğinde kadınlar ve erkekler arasında anlamlı bir fark bulunmuş ve bu farklılığın çevre genişletme ve özgüven boyutlarında olduğu görülmüştür. Ayrıca özçekim ölçeğinin alt boyutları cinsiyet değișkeni bağlamında ele alındığında, kadınların ortalamalarının, öznel uygunluk dışında tüm boyutlarda erkeklerin ortalamalarına göre daha yüksek olduğu görülmektedir. Nitekim Polonya'da Sabiniewicz, Borkowska, Serafinska ve Sorokowski (2017) tarafından yapılan araştırma, erkeklerin özellikle partnerleriyle yaptıkları özçekimler yoluyla akran grubu içerisinde statü sahibi olduklarını ortaya koymuştur. Kadınların ise özellikle ekledikleri filtreler sayesinde dış görünümleri üzerinden ruh hallerini iyileștirdikleri, akran grubundaki başka kadınlarla kendilerini karşılaştırarak kendilerine olan güvenlerini sağladıkları, yine dış görünüşleri üzerinden ilgi arama, dikkat çekme ve toplumsal çevrelerini genişletme güdüsüne sahip oldukları gözlenmiştir. Yapılan bir araştırmada da hem erkek hem de kadın kullanıcılar için gittiği yerleri tanıtmak, mutlu anları hatırlamak ve birlikte olduğu insanları göstermek en önemli güdüler olmaktadır (Uzun ve Uluçay, 2019). Bu araştırmada katılımcı olan iletişim öğrencilerinin -başka alanlarda öğrenim gören akranlarına oranla- daha sosyal, açık, girişken ve özgür davranış eğilimleri göstermesi nedeniyle geleneksel toplumsal cinsiyet rollerinden etkilenebilecek davranışlar ortaya çıkmamış ya da az çıkmış olabilir. $\mathrm{Bu}$ nedenle, gelecekte toplumsal cinsiyet temelli kalıpyargıların daha belirgin ve baskın olduğu gruplarda özçekim saplantısı düzeylerinin farklılaşıp farklılaşmadığı araştırılmalıdır.

Katılımcıların özçekim saplantısı öğrenim gördükleri üniversite türüne göre (devlet ya da vakıf) anlamlı bir farklılık göstermemiştir. Dolayısıyla, öğrencilerin özçekim saplantısı düzeylerinin öğrenim gördükleri devlet ya da vakıf üniversitelerine göre farklılaşıp farklılaşmayacağını belirlemek isteyen araştırma sorusuna da yanıt bulunmuştur. Ancak duygudurum değişikliği (mood modification) dişındaki tüm boyutlarda vakıf üniversitelerinde öğrenim gören öğrencilerin devlet üniversitelerinde öğrenim gören öğrencilerden görece daha yüksek ortalamaya sahip oldukları görülmüştür. Duygudurum değişikliği boyutunda ise iki grubun ortalaması birbirine eşit çıkmıştır. Buna göre vakıf üniversitelerindeki öğrencilerin, özçekim puanları devlet üniversitelerindeki öğrencilerle karşılaştırıldığında aritmetik anlamda genel olarak daha yüksek olmasına karşılık, aradaki farklar istatistiksel açıdan anlamlı değildir. Alanyazında bu konuda herhangi bir araştırmaya rastlanılmadığı için karşılaştırmalara dayalı bir tartışma yapmak olanaklı olmamıştır. Öyle görünüyor ki, özçekim yapma davranışı ya da alışkanlığı, maddi olanakları yansıtan ekonomik durum ile ilişkili olmaktan çok kişisel özelliklerden kaynaklanan psikolojik durum ile daha yakından ilişkilidir. Daha büyük örneklemler ve katılımcılar arasında daha keskin gelir farklılıklarını temel alan yeni araştırmalarda bu konu biraz daha incelenerek iyice açıklığa kavuşturulmalıdır.

Öğrencilerin özçekim saplantısına ilişkin toplam puanları araştırmaya katılan dört üniversiteye göre değerlendirildiğinde, üniversiteler arasında anlamlı farklar 
bulunmuştur. Buna göre Anadolu Üniversitesi'nin öğrencileri en düşük, Adnan Menderes Üniversitesi'nin öğrencileri ise en yüksek özçekim saplantısı puanlarına sahiptirler. İki vakıf üniversitesi arasında ise anlamlı bir fark gözlenmemiştir. Özçekim saplantısının alt boyutlarına yönelik ortalamalar üzerinden yapılan çözümlemeler de toplam puanların ortaya koyduğuna benzer bir sonuç sağlamıştır. Başka bir deyişle, alt boyutların tümünde de üniversiteler arasındaki farklar anlamlıdır. Özellikle Anadolu Üniversitesi ve Adnan Menderes Üniversitesi arasındaki farkları şehirlerin ve üniversitelerin özellikleri açıklamakta yararlı olabilir. Şehirlerin sağladığı sosyal olanaklar ya da üniversitelerin sahip olduğu özellikler mobil medyanın sunduğu kişisel/sanal sosyalleșme olanaklarından daha çok yararlanmaya ve yararlanmamaya yöneltebilmektedir.

Toplam özçekim puanları üzerinden yapılan testlerde öğrencilerin öğrenim gördükleri bölümler arasındaki farklar istatistiksel açıdan anlamlı bulunmuştur. Özellikle Yeni Medya ya da Dijital Medya gibi yeni iletişim alanlarını yansıtan bölümlerin yanı sıra, öğrenciler tarafından daha çok tercih edilen Halka İlişkiler ve Reklamcılık bölümlerinin puanları Basın ve Yayın ya da İletişim Tasarımı ve Yönetimi gibi bölümlere göre daha yüksektir. Duruma alt boyutlar açısından bakıldığında, özgüven ve öznel uygunluk boyutları dışındaki tüm boyutlarda gözlenen farklar anlamlı bulunmuştur. Yeni medyanın daha yakından incelendiği bölümlerde sayısal teknolojilerin mesleki konularda daha baskın olarak kullanıldığı bir gerçektir. Buna ek olarak, belki sunum, popülerlik, reklam ve güncellik gibi kavramlar yeni ya da çok yeğlenen bölümlerde biraz daha ön planda olduğu için bu bölümlerin öğrencileri özçekim yapma ve paylaşma gibi konuları kişisel kültürlerinin olağan bir parçası haline getirmiş olabilirler.

Öğrencilerin üniversitede hangi yılda ya da dönemde oldukları onların özçekim saplantısına ilişkin davranışlarını etkilemektedir. Ölçeğin tümünden elde edilen toplam puanlar üzerinde yapılan çözümlemelerde yıllar ve dönemler arasındaki farkların anlamlı olduğu gözlenmiştir. Alt boyutlar konusundaki çözümlemeler de, öznel uygunluk boyutu dışında, benzer sonuçlar sağlamıştır. Genel olarak alt sınıflarda olan öğrencilerin özçekim saplantısı puanları üst sınıflarda ya da dönemlerde olanlara göre, daha yüksektir. Aslında bu durum yaş değişkeni ile ilişkili görünmektedir. Gençler ya da yeni kuşaklar, sayısal iletişim teknolojilerini, yetişkinlere oranla daha sık ve yoğun kullanmaktadırlar. Belki bu durum, gençlerin sayısal yerliler, yetişkinlerin ise sayısal göçmenler olmasına ilişkin tartışmalarla ilişkilendirilebilir (Prensky, 2001). Sayısal yerli olarak varsayılan gençler yeni iletişim teknolojileri çağında dünyaya gelmişler, bu teknolojileri daha işlevsel kullanmayı öğrenmişler ve yaşamlarının her alanında yeni medyadan yararlanma yolunu seçmişlerdir. Her ne kadar üniversitenin ikinci sınıfındaki öğrenciler ile dördüncü sınıfındaki öğrenciler arasında çok büyük yaş ve kuşak farklılıkları yoksa da, iletişim teknolojilerindeki gelişme ve güncellemeler çok hızlı olup birkaç yılda bile kullanım davranış ve alışkanlıklarında farklılıklara neden olabilmektedir. Nitekim dönemler arasında bile anlamlı farkların ortaya çıkması dönüşümün ne kadar hızlı olduğunu göstermektedir. Gelecekteki araştırmalarda yeni iletişim teknolojilerinin ortaya çıkma, kullanım, yaygınlaşma ve terk edilme hızının yaşa göre katlamalı olduğu ileri sürülen etkileri yakından incelenmelidir.

Özçekim saplantısı ile katılımcıların sahip oldukları telefon markaları arasındaki ilişki incelendiğinde, değişik markaları kullananların toplam özçekim saplantısı puanlarına ilişkin ortalamalar arasındaki farklar anlamsız bulunmuştur. Ortalamalar açısından en büyük fark, iPhone kullanıcılarıyla başka kategorisinde yer alan markaların kullanıcıları arasında ortaya çıkmış olsa da özçekim saplantısı araştırma boyutları ile anlamlı bir 
ilişkiye sahip değildir. Telefonların artık genel olarak benzer özelliklere sahip olduğu düşünüldügünde, benzer kullanım ve etkilere sahip olabilmektedir. Ancak markalar konusunda gözlemlenen anlamlı farklılık, daha yeni olan akıllı (smart) telefonlar ile daha eski olan özellikli (feature) telefonlar arasındaki işlevsel farklardan kaynaklanmış olabilir.

Mobil telefonların günlük kullanım süresi öğrencilerin özçekim saplantılarını etkilemektedir. Hem toplam puanlar hem de alt boyut puanları arasında gözlemlenen farklar istatistiksel açıdan anlamlı bulunmuştur. Genel olarak, günlük kullanım süresi arttıkça özçekim saplantı düzeyinde de bir yükselme gözlenmektedir. Aslında mobil telefonunu günlük olarak sık ve yoğun kullanan öğrenciler için özçekim yapmak, mobil telefonla kurulan iletişimin olağan bir parçasıdır. Anlık bir durumu kayıt altına almak isteyen bir kullanıcı hemen özçekim yapmakta ve bunlardan bazılarını başkalarıyla paylaşmaktadır. Özellikle genç kullanıcılar için hemen her iş mobil telefonla yapılabilmekte, deyim yerindeyse bu kullanıcılar "telefonum varsa her şeyim var" psikolojisi içinde davranmaktadırlar. Alanyazında yakınsama olarak adlandırılan bu kavram, gençlerin yaşamında daha somut gözlenmektedir. Dolayısıyla, her işini mobil telefonla yapan bir kullanıcı daha çok özçekim yapmakta ve paylaşmaktadır. Nitekim Pandey ve Mishra'nın (2017) araștırma sonuçları bunu destekler niteliktedir.

$\mathrm{Bu}$ araştırma üniversite düzeyinde ve yalnızca iletişim fakültelerinde öğrenim gören öğrenciler üzerinde yapılmıştır. Gelecekteki araștırmalar farklı eğitim düzeylerine ve öğrenim alanlarına dönük olarak yapılırsa, sorunu daha geniş bir bakış açısıyla tartışma olanağı ortaya çıkacaktır. Bu araştırma 613 lisans öğrencisiyle yapılmıştır. Tekil bir araştırma için bu sayı pek de düşük değildir ama gelecekte ulusal ölçekte yürütülecek araştırma projeleriyle çok daha büyük örneklemlerden veri toplanabilir. Böylece hem ulusal durumu görmek hem de başka ülkelerle karşılaştırmalar yapmak olanaklı olabilir. $\mathrm{Bu}$ araştırma sınırlı sayıda kişisel ve demografik değişken üzerinden yapıldığı için nicel ve ilişkisel düzeyde kalmıştır. Gelecekteki araştırmalarda derinlemesine nitel yaklaşımlar işe koşularak daha olgubilimsel ve kültür temelli açıklamalara ulaşılabilir. Son olarak, bu araştırma özçekim davranışı ve onun alt boyutlarına odaklanmıştır. Yeni yapılacak araştırmalarda -tartışmalı da olsa- ruhsal bir bozukluk olarak nitelendirilen özçekim saplantısıyla öteki psikolojik rahatsızlıklar arasındaki ilişkiler araştırılabilir. Böylece, belki çözüm konusunda da işe yarar ipuçları elde edilebilir.

\section{Notlar}

1 Özçekim kavramı, Türk Dil Kurumu tarafından Ingilizce'deki selfie sözcüğüne karşıllık olarak önerilmiştir.

\section{Kaynakça}

Balakrishnan, J. ve Griffiths, M. (2018). An exploratory study of "selfitis" and the development of the selfitis behavior scale. International Journal of Mental Health and Addiction, 16. doi:10.1007/s11469-017-9844-x

Bazarova, N. N. ve Choi, Y. H. (2014). Self-disclosure in social media: extending the functional approach to disclosure motivations and characteristics on social network sites. Journal of Communication, 64(4), 635-657. doi:10.1111/ jcom.12106

Bergkvist, U. (2016). The dark triad as predictors of selfie behaviour: The role of narcissism, Machiavellianism and psychopathy. Dublin Business School. 
Buffardi, L. E. ve Campbell, W. K. (2008). Narcissism and social networking web sites. Personality and Social Psychology Bulletin, 34(10), 1303-1314. doi:10.1177/0146167208320061

Donitta, A. (2017). Selfitis -A Mental Disorder. International Journal of Science and Research, 6(4), 985-986.

Döring, N., Reif, A. ve Poeschl, S. (2016). How gender-stereotypical are selfies? A content analysis and comparison with magazine adverts. Computers in Human Behavior, 55, 955-962. doi:https://doi.org/10.1016/j.chb.2015.10.001

Ellison, N., Heino, R. ve Gibbs, J. (2006). Managing Impressions Online: Self-Presentation Processes in the Online Dating Environment. Journal of Computer-Mediated Communication, 11(2), 415-441. doi:10.1111/j.1083-6101.2006.00020.x

Etgar, S. ve Amichai-Hamburger, Y. (2017). Not all selfies took alike: Distinct selfie motivations are related to different personality characteristics. Frontiers in Psychology, 8.

Fox, J. ve Rooney, M. C. (2015). The Dark Triad and trait self-objectification as predictors of men's use and self-presentation behaviors on social networking sites.

Personality and Individual Differences, 76, 161-165. doi:https://doi.org/10.1016/j. paid.2014.12.017

Georgakopoulou, A. (2016). From narrating the self to posting self(ies): A small stories approach to selfies. Open Linguistics, 2(1), 300-317. doi:https://doi.org/10.1515/ opli-2016-0014

Halpern, D., Valenzuela, S. ve Katz, J. E. (2016). “Selfie-ists” or "Narci-selfiers”?: A crosslagged panel analysis of selfie taking and narcissism. Personality and Individual Differences, 97, 98-101. doi:https://doi.org/10.1016/j.paid.2016.03.019

Holiday, S., Lewis, M. J., Nielsen, R., Anderson, H. D. ve Elinzano, M. (2016). The selfie study: Archetypes and motivations in modern self-photography. Visual Communication Quarterly, 23(3), 175-187. doi:10.1080/15551393.2016.1223548

Katz, J. ve Crocker, E. T. (2015). Selfies and photo messaging as visual conversation: Reports from the United States, United Kingdom, and China. International Journal of Communication, 9, 1861-1872.

Lee, E., Lee, J.-A., Moon, J. H. ve Sung, Y. (2015). Pictures speak louder than words: Motivations for using Instagram. Cyberpsychology, behavior and social networking, 18, 552-556. doi:10.1089/cyber.2015.0157

Losse, K. (2013). The return of the selfie. The New Yorker, 5.

Malik, A., Dhir, A. ve Nieminen, M. (2016). Uses and Gratifications of digital photo sharing on Facebook. Telematics and Informatics, 33(1), 129-138. doi:https://doi. org/10.1016/j.tele.2015.06.009

McConnell, K. A. (2015). Photography, physiognomy, and revealed truth in the Antebellum Sout. The Southern Quarterly, 52(4), 32-53.

Mehdizadeh, S. (2010). Self-Presentation 2.0: Narcissism and self-esteem on Facebook. Cyberpsychology, Behavior, and Social Networking, 13(4), 357-364. doi:10.1089/ cyber.2009.0257 
Oxford Dictionaries. (2013). The Oxford Dictionaries Word of the Year 2013 is... Selfie. OxfordWords (blog). https://www.bbc.com/news/uk-24992393 adresinden erişildi.

Pandey, V. ve Mishra, P. (2017). Assess the relationship between selfies and self esteem among university students. Journal of Humanities and Social Science, 22(12), 2430.

Paris, C. M. ve Pietschnig, J. (2015). 'But first, let me take a selfie': Personality traits as predictors of travel selfie taking and sharing behaviors. ttra International Conference içinde . https://scholarworks.umass.edu/cgi/viewcontent. cgi?article $=1138 \&$ context=ttra adresinden erişildi.

Peraica, A. (2017). Culture of the selfie: self-representation in contemporary visual culture. Institute of Network Cultures. http://networkcultures.org/wp-content/ uploads/2017/05/CultureOfTheSelfie.pdf adresinden erişildi.

Prensky, M. (2001). Digital Natives, Digital Immigrants Part 1. On the Horizon, 9, 1-6. doi:10.1108/10748120110424816

Sabiniewicz, A., Borkowska, B., Serafińska, K. ve Sorokowski, P. (2017). Is love related to selfies? Romantic selfie posting behavior and love levels among women and men. Personality and Individual Differences, 111, 297-300. doi:https://doi. org/10.1016/j.paid.2017.02.038

Saltz, J. (2014). Art at arm's length: A history of the selfie. New York Magazine, 47(2), 71-75.

Shin, Y., Kim, M., Im, C. ve Chong, S. C. (2017). Selfie and self: The effect of selfies on selfesteem and social sensitivity. Personality and Individual Differences, 111, 139-145. doi:https://doi.org/10.1016/j.paid.2017.02.004

Sorokowski, P., Sorokowska, A., Frackowiak, T., Huk, A. ve Pisanski, K. (2015). Selfie posting behaviors are associated with narcissism among men. Personality and Individual Differences, 85. doi:10.1016/j.paid.2015.05.004

Sung, Y., Lee, J.-A., Kim, E. ve Choi, S. M. (2016). Why we post selfies: Understanding motivations for posting pictures of oneself. Personality and Individual Differences, 97, 260-265. doi:https://doi.org/10.1016/j.paid.2016.03.032

Şimşek, A. (2020). Özçekim saplantısı. Yeni medyanın karanlık yüzü içinde (ss. 277-302). Ankara: Nobel.

Tabachnick, B. G. ve Fidell, L. S. (2013). Using multivariate statistics: International edition. Pearson Boston, MA.

Uzudumlu, Ö. (2015). Bir iletişim unsuru olarak sosyal selfie uygulamaları. Atatürk İletişim Dergisi, (8), 227-248.

Uzun, K. ve Uluçay, D. M. (2019). Özçekim (Selfie) Fotoğrafları Sosyal Ağlarda Paylaşma Ve Paylaşmama Nedenleri. Erciyes İletişim Dergisi, 6(2), 1121-1140. doi:10.17680/erciyesiletisim.487073

Wallop, H. (2014). Ellen DeGeneres Oscar selfie-how it defines our age. The Telegraph. https://www.telegraph.co.uk/culture/ film/oscars/10673064/Ellen-DeGeneresOscar-selfie-how-it-defines-ourage.html adresinden erişildi. 
Wang, R., Yang, F. ve Haigh, M. M. (2017). Let me take a selfie: Exploring the psychological effects of posting and viewing selfies and groupies on social media. Telematics and Informatics, 34(4), 274-283. doi:https://doi.org/10.1016/j.tele.2016.07.004

Weiser, E. B. (2015). \#Me: Narcissism and its facets as predictors of selfie-posting frequency. Personality and Individual Differences, 86, 477-481. doi:https://doi. org/10.1016/j.paid.2015.07.007

Zetlin, M. (2019). Taking Selfies Destroys Your Confidence and Raises Anxiety, a Study Shows. Why Are You Still Doing It? https://www.inc.com/minda-zetlin/takingselfies-anxiety-confidence-loss-feeling-unattractive.html adresinden erișildi. 


\title{
Selfie Behaviors of University Students: A Study on Communication Students as Active Users of New Media
}

\author{
Ali Şimşek (Prof. Dr.) \\ Taner Kızılhan (Res. Asst. Ph.D.) \\ Kemal Elciyar (Res. Asst. Ph.D.)
}

\section{Extended Abstract}

The fact that smartphones have the capability to take photos and develop this capability day by day has significantly increased the prevalence of photos in everyday life. Consequently, photo-based social networks have also increased their number of users. Many users share their photos on these networks for various purposes. Selfies are probably the most common and the most popular among these photos. The concept of selfie was named as the word of the year by Oxford in 2013 (Oxford Dictionaries, 2013). Although technical possibilities brought selfies to the forefront in recent years, the first selfie was made by Robert Cornelius after a process called "daguerreotype" (McConnell, 2015). In particular, the excessive number of shared selfies and the meanings attributed to selfies have revealed obsessive feelings and behaviors. In the literature, such uses are described in short as "selfitis" (Balakrishnan and Griffiths, 2018). In plain language, it is possible to describe selfitis as "selfie obsession". Selfitis is seen as a psychological disorder for reasons such as being addictive, affecting a person's relationships with their environment negatively, and revealing physical appearance as a problem (Donitta, 2017, p. 985). It is also considered to be associated with other mental constructs and disorders such as obsessive-compulsive disorder, body dysmorphic disorder, and narcissism (Bergkvist, 2016, p. 6). Users can create stories with selfies they share (Georgakopoulou, 2016), to fulfill different purposes such as seeking information, communicating, archiving, and having fun (Sung et al., 2016)particularly selfies (pictures one takes of oneself.

The present study, which aimed at identifying selfie behaviors of communication students in selected Turkish universities, was conducted as a survey study and random sampling was used. Data were collected from communication faculties of 2 state universities (Anadolu and Adnan Menderes) and 2 foundation universities (Başkent and İzmir Ekonomi). Through this operational categorization, it was intended to examine whether the socio-economic situation also had an impact on students' selfie behaviors. The sample of the study consisted of 613 undergraduate students, of which 348 (57\%) were from state universities and 265 (43\%) were from foundation universities. Participants were students of seven different departments in the field of communication; of them $335(55 \%)$ were female and 278 (45\%) were male. All participants reported owning a personal smartphone. In terms of mobile phone brand, Apple came first (52\%), followed by Samsung (26\%), Huawei (15\%), and others (7\%). Approximately $73 \%$ of participants indicated that they use their smartphones for 1-5 hours per day. The fact that $23 \%$ of the participants use smartphones over five hours a day reveals the role of mobile technologies in their everyday life. In the present study, the selfie behaviors were identified through administration of the Selfitis Behavior Scale developed by Balakrishnan and Griffiths (2018). This scale examines selfitis with six sub-dimensions: environment enhancement, social competition, attention seeking, mood modification, self-confidence, and subjective conformity. The possible effects of demographic variables on selfitis behaviors including its sub-dimensions was examined by using multivariate analysis of variance (MANOVA). 
Results suggested that significant gender effects were observed on the sub-dimensions of environmental enhancement and self-confidence. Female students had higher mean scores in both dimensions than male students. Females believe that sharing selfies increases their self-confidence, improves their memories, and makes them have a better time in their social circle. Although there were no significant differences in terms of university type (state versus foundation), significant differences were detected when individual universities were compared with each other. Students in Adnan Menderes University (the newest among the four faculties in the sample) had the highest selfitis mean scores on all sub-dimensions, while students in Anadolu University (the oldest faculty in the sample) had the lowest selfitis mean scores. There were significant differences among the departments of study in terms of four sub-dimensions of selfitis such as environment enhancement, social competition, attention seeking, and mood modification. The years of study at the university were divided into three groups: the second year, the third year and the fourth year. The first-year students were not included in the study because they were new as communication majors. Regarding this variable, significant differences were observed in the dimensions of environment enhancement, social competition, attention seeking, mood modification, and self-confidence. In general, the participants in the upper years of study had lower means. No significant difference was found related to mobile phone brands, but duration of daily phone usage and selfitis sub-dimensions demonstrated meaningful relationships. As the duration of use increases, the level of selfitis also increases.

Considering the participants' overall mean score of the selfitis behaviors $(M=2,06)$, it can be stated that the general level of selfitis in the sample is low. Looking at the means of subdimensions, the highest value was in environment enhancement $(M=2,55)$ and the lowest value was in subjective conformity $(M=1,60)$. These values are below the threshold value both for overall selfitis level and its sub-dimensions. This result alone may be interpreted that communication students behave carefully or consciously about their selfie behaviors. Differences for gender can be explained by the fact that participants consist of students of the faculties of communication. That is, because communication students who participated in this study typically show relatively more social and free behavioral tendencies than their peers in other fields, different behaviors that could be influenced by traditional gender roles did not occur or may have been minimal at the general selfitis level. The differences that arise for individual universities can be explained by particular characteristics of universities and their student profiles. Regarding the impact of the years of study, mean selfitis scores of students in the lower years are higher than those in the upper years. The fact that the dominating brands in the global smartphone market have very similar features can be instrumental in explaining that there are no significant differences particularly among the leading brands when it comes to their impact on selfitis. In addition, an increase in the level of selfitis is observed as daily duration of usage increases. In fact, for individuals who use their mobile phones excessively on a daily basis, taking selfies is an ordinary part of their mobile communication.

Keywords: Communication, Selfie, Selfitis, Selfie Behaviors, Mobile Phone, University Students. 
Bu makale intihal tespit yazılımlarıly taranmıştır. İtihal tespit edilmemiştir.

This article has been scanned by plagiarism detection softwares. No plagiarism detected.

Bu çalışmada "Yükseköğretim Kurumları Bilimsel Araştırma ve Yayın Etiği Yönergesi” kapsamında uyulması belirtilen kurallara uyulmuştur.

In this study, the rules stated in the "Higher Education Institutions Scientific Research and Publication Ethics Directive" were followed.

Yazarların çalışmadaki katkı oranları; birinci yazar $\% 40$, ikinci yazar $\% 30$, üçüncü yazar $\% 30$.

Contribution rates of the authors in the study; first author $40 \%$, second author $30 \%$, third author $30 \%$.

Çalışma kapsamında herhangi bir kurum veya kişi ile çıkar çatışması bulunmamaktadır.

There is no conflict of interest with any institution or person within the scope of the study.

\section{Etik Kurul İzni I Ethics Committee Permission}

Anadolu Üniversitesi Sosyal ve Beşeri Bilimler Bilimsel Araşııma ve Etik Kurulu'nun 26.04.2018 tarih ve 43348 numaralı toplantıında alınan karar çerçevesinde çalışma etik açıdan bir sakınca içermemektedir.

Within the framework of the decision taken during the meeting by Anadolu University Social and Human Sciences Scientific Research and Publication Ethics Committee dated 26.04.2018 and numbered 43348; the study does not contain any ethical issues. 